\title{
30. STABLE OXYGEN AND CARBON ISOTOPE VARIATIONS IN THE PORE WATERS, CARBONATES AND SILICATES, SITES 225 AND 228, RED SEA ${ }^{1}$
}

\author{
J. R. Lawrence, ${ }^{2}$ Lamont-Doherty Geological Observatory, \\ Columbia University, Palisades, New York
}

\section{INTRODUCTION}

The Red Sea is a basin semi-isolated from the open ocean in a region of the earth's crust that is subject to high heat flow. Because of the restricted flow of water to and from the Indian Ocean and the high evaporation rate at these low latitudes, the waters of the Red Sea probably have undergone large fluctuations in $\mathrm{O}^{18} / \mathrm{O}^{16}$ content, salinity, and temperature as a result of glacially induced eustatic changes in sea level in the Pleistocene and possible tectonic events since the Miocene (Deuser and Degens, 1969). Also, because of high temperatures in the sediments resulting from high heat flow, recrystallization is more likely than in other marine sediments. Such recrystallization can cause significant changes in the $0^{18} / 0^{16}$ of pore waters and carbonates and silicates in the sediments. The basic object of this investigation therefore was to determine to what degree isotopic variations yield information about changes in the $\mathrm{O}^{18} / \mathrm{O}^{16}$ content and temperatures of Red Sea waters as opposed to information about the nature of recrystallization of the sediments.

The sediments from Sites 225 and 228 consist of a late Miocene evaporite sequence overlain by a sequence of Plio-Pleistocene silty oozes, chalks, and calcareous siltstones. The Plio-Pleistocene sediments generally have carbonate contents of 30 to 65 percent, while the Miocene section generally contains less than 25 percent carbonate.

\section{PROCEDURE}

Pore waters and sediments were sampled at 10 to 20 horizons at each site. Immediately after squeezing of the $10-\mathrm{cm}-$ long inner portion of the core for pore water analysis, approximately $1 \mathrm{ml}$ of pore water was sealed in a glass vial using a torch. A few months later the $\mathrm{O}^{18} / \mathrm{O}^{16}$ analyses were made utilizing the methods of O'Neil and Epstein (1966).

Because of the very high gradients in salinity and doubly charged ions, the possibility of systematic errors being introduced into the $\mathrm{O}^{18} / \mathrm{O}^{16}$ data of water samples was examined. Salts remaining after the transfer of the water sample to the reaction vessel, particularly those containing doubly charged ions, will contain water of hydration which might be of an $\mathrm{O}^{18} / \mathrm{O}^{16}$ composition different from that

\footnotetext{
${ }^{1}$ Lamont-Doherty Geological Observatory Contribution No. 2030.

${ }^{2}$ The author gratefully acknowledges financial support for this work by the National Science Foundation under contract GA 17724.
}

of the entire water sample. The amounts of these salts would be a function of cation differences from sample to sample, making systematic errors possible.

Table 1 contains a compilation of data on artificial seawater (ASW) samples with a large variation in $\mathrm{Mg}^{+2}$ and $\mathrm{Ca}^{+2}$ concentrations. All samples were prepared from a single water by adding variable amounts of salts. No systematic errors were observed as a function of changes in the $\mathrm{Ca}^{+2}$ and $\mathrm{Mg}^{+2}$ concentrations. However, comparison of the blank with the artificial seawaters suggests that a systematic error on the order of $1 \%$ may exist. A water with a specific $\mathrm{O}^{18} / \mathrm{O}^{16}$ value and a salt content similar to that of seawater yields a $\delta \mathrm{O}^{18}$ analysis $\sim 1^{\circ} \%$ o lower than the same water containing no salt when analyzed by the method of O'Neil and Epstein (1966). It is therefore advisable to use seawater of a known $\mathrm{O}^{18} / \mathrm{O}^{16}$ as the analytical running standard. All samples in this report were analyzed using a seawater standard. The analytical precision for salt water standards is $\pm 0.43^{\circ} \%$ o compared to $\pm 0.16^{\circ} \%$ o for pure water standards (see Table 1). Friedman (personal communication) has indicated that the addition of $\mathrm{NaF}$ to salt waters will markedly improve the precision of the analyses.

Bulk silicates and carbonates were also investigated. A portion of the cake remaining from the squeezing was sealed in an airtight bag for later analysis. The sediment samples were air dried and ground in mortar and pestle. These bulk samples, representing stratigraphic horizons 10 $\mathrm{cm}$ thick, were analyzed for the $\mathrm{O}^{18} / \mathrm{O}^{16}$ and $\mathrm{C}^{13} / \mathrm{C}^{12}$ content of the carbonate fraction by the method described by McCrea (1950). A separate portion of the bulk sediment was treated with a sodium acetate-acetic acid buffer to remove the carbonate. This carbonate-free portion was analyzed for $\mathrm{O}^{18} / \mathrm{O}^{16}$ by the method of Clayton and Mayeda (1963). All $\mathrm{O}^{18} / \mathrm{O}^{16}$ and $\mathrm{C}^{13} / \mathrm{C}^{12}$ analyses are reported with respect to SNOW and PDB, respectively.

\section{DISCUSSION OF RESULTS}

\section{Site 228}

The pore waters from Site 228 exhibit a very large decrease in $0^{18} / \mathrm{O}^{16}$ with depth. The near-surface pore water $\left(6 \mathrm{~m}\right.$ in depth) has a $\delta \mathrm{O}^{18}$ of $+1.6 \pm 0.2^{\circ} \%$, very near that of Red Sea water with a salinity of $40 \%$ o (see Figure 1). The pore water at 306 meters has $\delta \mathrm{O}^{18}=-3.3 \pm 0.4^{\circ} \%$ 。

Possible explanations for the steep gradient in $\mathrm{O}^{18} / \mathrm{O}^{16}$ include (1) the influx of meteoric water from the continents through aquifiers, (2) residual ancient Red Sea water having a high meteoric water content, (3) diagenetic alteration in the sediments with an authigenic component taking up a high $\mathrm{O}^{18}$ content in comparison with its 
TABLE 1

Precision and Accuracy of $0^{18} / 0^{16}$ Data of Water Standards and Artificial Seawaters ${ }^{\mathrm{a}}$ Containing

Variable Amounts of $\mathrm{Ca}^{+2}$ and $\mathrm{Mg}^{+2}$ Using the Method of O'Neil and Epstein (1966)

\begin{tabular}{|c|c|c|c|c|}
\hline Description & $\begin{array}{c}\mathrm{Ca}^{+2} \\
(\mu \mathrm{g} / \mathrm{ml})\end{array}$ & $\underset{(\mu \mathrm{g} / \mathrm{ml})}{\mathrm{Mg}^{+2}}$ & $8 \mathrm{O}^{18}$ & $\begin{array}{c}\text { Average } \\
\text { Deviation }\end{array}$ \\
\hline \multirow[t]{2}{*}{$\mathrm{ASW}^{\mathrm{b}} 1$} & 400 & 1250 & $\begin{array}{r}-10.08 \\
-11.03 \\
-8.95 \\
-10.15\end{array}$ & \\
\hline & & & -10.05 & \pm 0.55 \\
\hline \multirow[t]{2}{*}{ ASW 2} & 820 & 615 & $\begin{array}{l}-9.21 \\
-9.54\end{array}$ & \\
\hline & & & -9.38 & \pm 0.16 \\
\hline ASW 3 & 600 & 915 & -10.17 & \\
\hline \multirow[t]{2}{*}{ ASW 4} & 1020 & 500 & $\begin{array}{r}-10.13 \\
-9.30\end{array}$ & \\
\hline & & & -9.71 & \pm 0.41 \\
\hline \multirow[t]{2}{*}{ Blank } & 0 & 0 & $\begin{array}{l}-8.64 \\
-8.56\end{array}$ & \\
\hline & & & -8.61 & \pm 0.03 \\
\hline $\begin{array}{l}\text { Distilled Waters } \\
\text { (NBS-1, W-1) }\end{array}$ & 0 & 0 & & $\pm 0.19^{\circ} \%$ \\
\hline \multicolumn{5}{|l|}{10 analyses } \\
\hline $\begin{array}{l}\text { Seawater } \\
\text { Standards } \\
\text { (R5, ASW) }\end{array}$ & $400-1000$ & $500-1250$ & & $\pm 0.43^{\circ} \%$ \\
\hline 23 analyses & & & & \\
\hline
\end{tabular}

${ }^{\mathrm{a}} \mathrm{Na}^{+}$and $\mathrm{K}^{+}$concentrations were held constant at 10,000 and 800 $\mu \mathrm{g} / \mathrm{ml}$, respectively.

${ }^{\mathrm{b}} \mathrm{ASW}=$ artificial seawater

pre-diagenetic precursor (Lawrence, in press), or (4) a deep source of low $\mathrm{O}^{18}$ water resulting from the alteration of basalt to clay minerals or zeolites.

The first and second explanations can only account for a small part of the observed $\mathrm{O}^{18}$ change because the $\mathrm{D} / \mathrm{H}$ measurements (Friedman, this volume) do not indicate such low $\mathrm{O}^{18}$ values for the pore waters if the $\mathrm{D} / \mathrm{H}$ values reflect the meteoric input. The gradient in $\mathrm{D} / \mathrm{H}$ from top to bottom exhibits a decrease of approximately $10 \%$. The corresponding gradient in $\mathrm{O}^{18}$ would only decrease by $1.3 \%$ (Craig, 1961).

The third explanation requires than an authigenic component making up more than $20 \%$ of the total solids be found in the sediment column with a high $\mathrm{O}^{18}$ content compared to its pre-diagenetic precursor. The carbonate fraction of the sediment above 220 meters is not a likely candidate because the $\mathrm{O}^{18} / \mathrm{O}^{16}$ of the carbonates (see Figure 2) exhibits little change with depth. The formation of a large amount of authigenic silicate such as montmorillonite $\left(\delta \mathrm{O}^{18} \sim+22\right.$ to $+28^{\circ} \%$ ) at depth could explain the observed gradient in $\mathrm{O}^{18} / \mathrm{O}^{16}$ in pore waters if its pre-diagenetic counterpart were volcanic ash or igneous detritus $\left(\delta \mathrm{O}^{18} \sim+6\right.$ to $+12^{\circ} \%$ ) (Lawrence, in press).

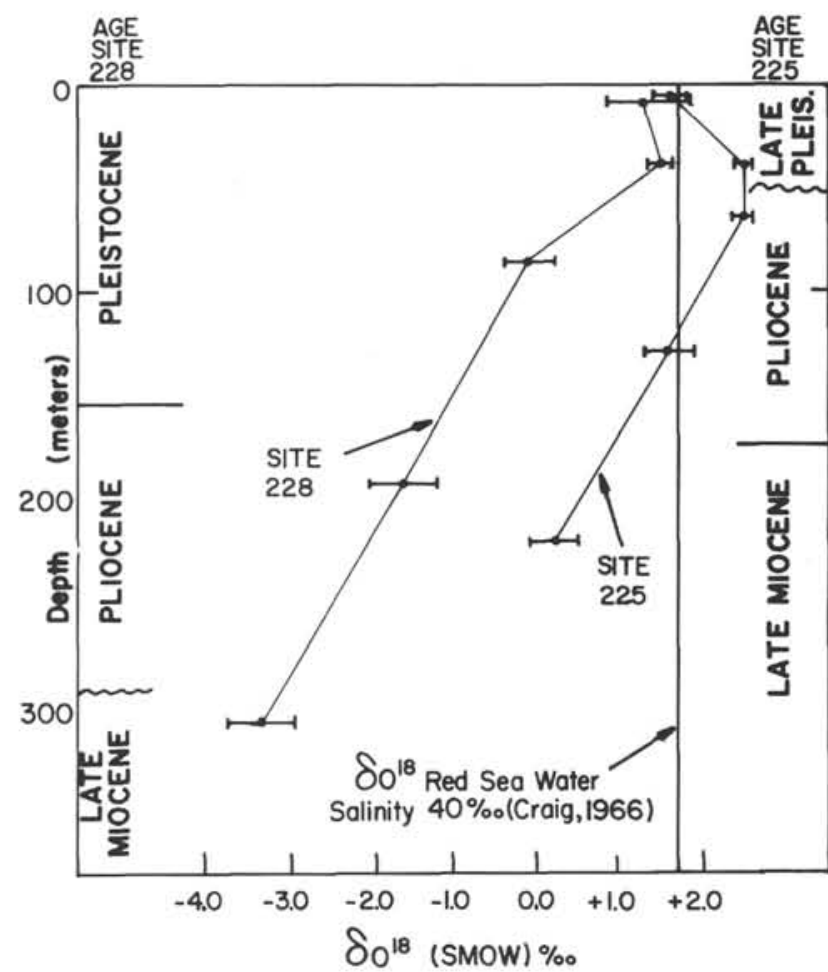

Figure 1. $80^{18}$ of the pore waters (relative to SMOW) from Sites 225 and 228 plotted as a function of depth. Error bars show the average deviation of two analyses.

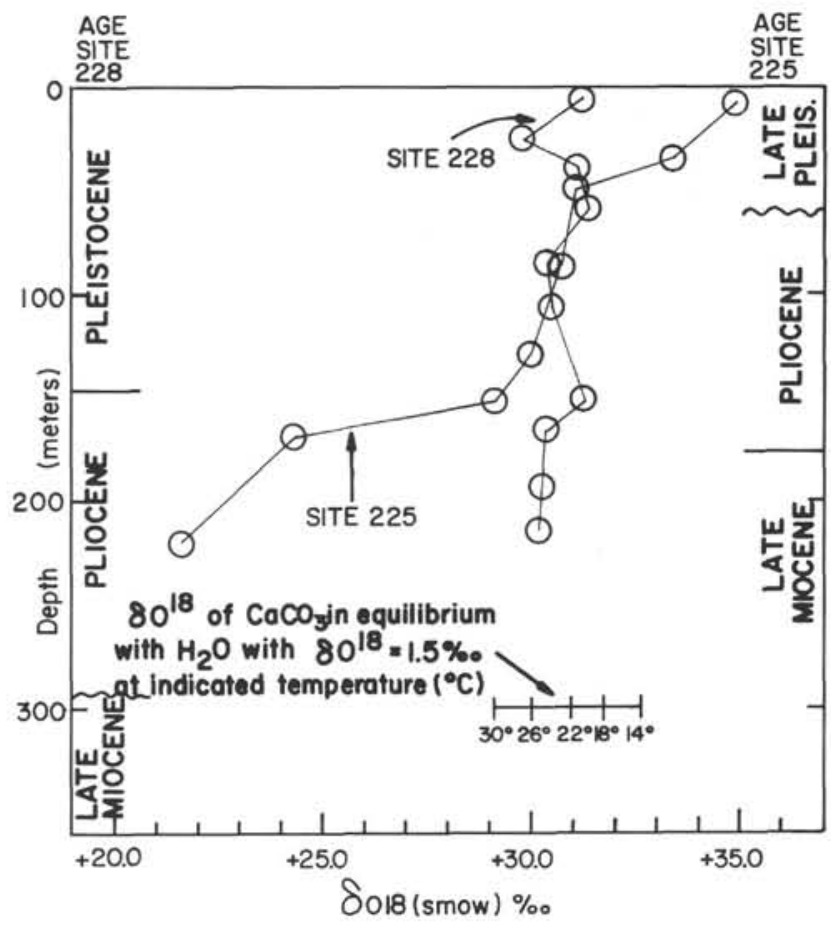

Figure 2. $\delta O^{18}$ of the bulk carbonate (relative to SMOW) from Sites 225 and 228 plotted as a function of depth. 
Investigation of this possibility requires a careful examination of the silicate fraction of the sediment at a large number of horizons. However, no general increase in the $\mathrm{O}^{18} / \mathrm{O}^{16}$ of the bulk silicate with depth is found (see Table 2), apparently indicating that there is no large general increase in the authigenic silicate content of the sediment with depth. In fact, the $\delta \mathrm{O}^{18}$ of the bulk silicates are within the range expected for unaltered continental detritus (Savin and Epstein, 1970).

The fourth explanation could account for the observed decrease in $\mathrm{O}^{18} / \mathrm{O}^{16}$ in the pore waters if basalts underlying the sedimentary column have been undergoing a significant degree of alteration to clay minerals and zeolites during the deposition of the sediments. The testing of this hypothesis will require age dating and $0^{18} / \mathrm{O}^{16}$ analysis of alteration products of basalts underlying ocean sediments. The phenomenon of decreasing $\mathrm{O}^{18} / \mathrm{O}^{16}$ with depth in pore waters of ocean sediments has been found also at Sites 149, 148, and 157 of DSDP (Lawrence, in press; Sakai, personal communication).

\section{Site 225}

The pore waters from Site 225 in contrast to those of Site 228 exhibit an increase in $\delta \mathrm{O}^{18}$ from $+1.3 \pm 0.5^{\circ} \%$ (near that of Red Sea water with a salinity of $40^{\circ} \%$ ) to a maximum of $+2.5 \pm 0.1^{\circ} \%$ near 50 meters, followed by a decrease to to. $2 \pm 0.3 \%$ at 220 meters (see Figure 1). The $\delta \mathrm{O}^{18}$ values correlate well with the $\delta \mathrm{D}$ data of Friedman (this volume). This suggests that the observed isotopic variations are a result of (1) changes in the evaporation rate from and fresh water input to the Red Sea, (2) a variation in the exchange of Red Sea water with the open ocean, and/or (3) changes in the influx of meteoric waters into the sediments of the Red Sea via aquifers with a continental inlet.

The high $\mathrm{O}^{18} / \mathrm{O}^{16}$ values of the pore waters in the vicinity of 50 meters could be explained by a change in the $\delta \mathrm{O}^{18}$ of the Red Sea from the late Pleistocene to the Recent. Deuser and Degens (1969) suggested a sudden increase going back in time in the vicinity of 11,000 years B.P. in the $\mathrm{O}^{18} / \mathrm{O}^{16}$ of the Red Sea water of a few per mil. They suggested that this was a result of "lowering of sea level in response to continental glaciations reducing the water exchange at the southern end of the Red Sea or tectonic activity near the Strait of Bab el Mandeb." Diffusion and perhaps advection of water into the sediments from 80,000 to 10,000 B.P. would raise the $\mathrm{O}^{18} / \mathrm{O}^{16}$ of the pore waters. From 10,000 B.P. to the present a shift in the isotopic content of Red Sea water to present values would slowly lower by diffusion and advection, the $\mathrm{O}^{18} / \mathrm{O}^{16}$ of the pore waters conceivably yielding the observed maximum in the $\mathrm{O}^{18} / \mathrm{O}^{16}$ of the pore waters seen at 40-60 meters depth in sediment column (Figure 1). This explanation requires that Red Sea waters have a $\delta \mathrm{O}^{18}$ greater than $+2.5^{\circ} \%$ o before 10,000 B.P. The fact that such a large positive anomaly was not seen in the pore waters of Site 228 could be a result of lower diffusive and advective rates in the pore waters as a result of generally lower temperatures at Site 228.

The $\delta \mathrm{O}^{18}$ of the bulk carbonates from Site 225 decreases from $+35^{\circ} \%$ o to $+22 \%$ as a function of depth.
TABLE 2

$\mathrm{O}^{18} / \mathrm{O}^{16}$ of Bulk Silicates, Site 228

\begin{tabular}{cc}
\hline Depth $(\mathrm{m})$ & $\delta \mathrm{O}^{18}(\mathrm{SMOW})(\%$ ) \\
\hline 6 & +18.1 \\
85 & +12.6 \\
194 & +11.7 \\
250 & +10.5 \\
307 & +15.3 \\
\hline
\end{tabular}

The $\delta \mathrm{C}^{13}$ values down to 130 meters are in the 0 to $+2 \%$ o range, characteristic of fossils living in seawater. Below that the $\delta \mathrm{C}^{13}$ of the bulk carbonate decreases to a low value of $-8.7 \%$ (Figure 3 ). The carbonate does not exhibit any significant degree of lithification above 130 meters, but below that partial lithification and the presence of pyrite, dolomite, and an evaporite sequence indicates extensive recrystallization. The extreme low values in $\mathrm{O}^{18}$ and $\mathrm{C}^{13}$ below 130 meters require that recrystallization must have taken place at high temperatures and/or in the presence of low- $\mathrm{O}^{18}$ water. A source of deplete $\mathrm{C}^{13} / \mathrm{C}^{12}$ is also required during the recrystallization. Above 130 meters the $\delta \mathrm{O}^{18}$ and $\delta \mathrm{O}^{13}$ of the bulk carbonate in the oozes, with the exception of two high-O $\mathrm{O}^{18}$ values in the late Pleistocene, are compatible with fossils growing in a water like that of present-day Red Sea surface water. The two high $\delta \mathrm{O}^{18}$ values are indicative of growth of fossils in or equilibration of the carbonate with a water of a higher $\mathrm{O}^{18} / \mathrm{O}^{16}$ and/or lower temperature than either present-day Red Sea surface or deep water. Deuser and Degens (1969) in investigating aragonite encrusted pteropods suggested precipitation of secondary aragonite from a high $\mathrm{O}^{18} / \mathrm{O}^{16}$ pore water prior to 10,000 B.P. This hypothesis explains the $0^{18} / \mathrm{O}^{16}$ variations of both the pore waters and carbonates in the late Pleistocene from Site 225.

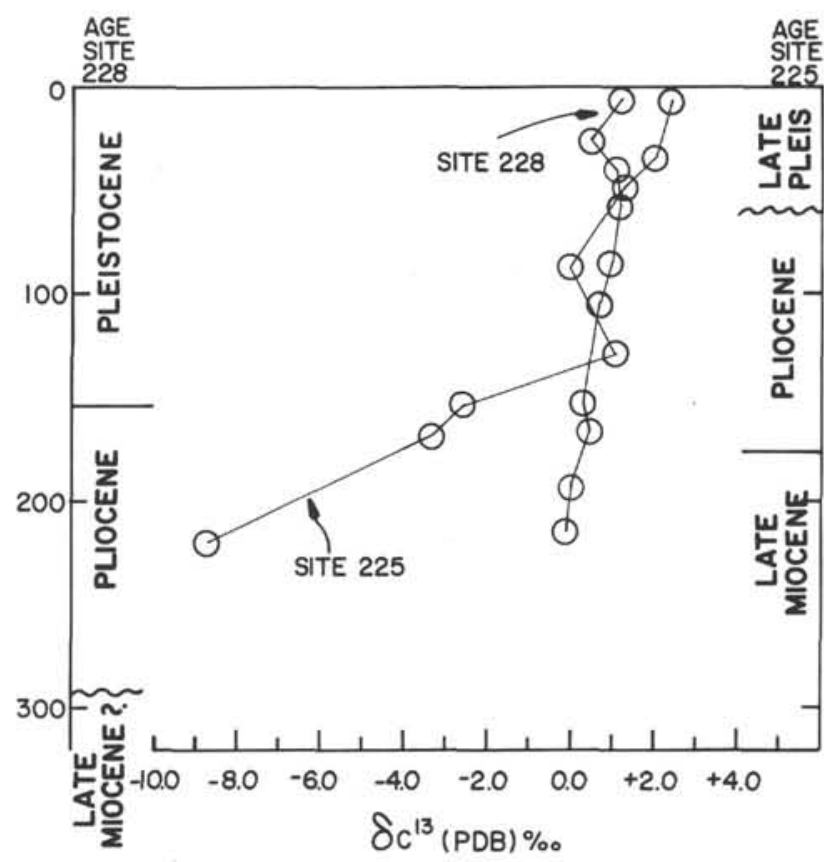

Figure $3 . \delta C^{13}$ of the bulk carbonate (relative to $P D B$ ) from Sites 225 and 228 plotted as a function of depth. 


\section{J. LAWRENCE}

Because Site 225 is in an area of high heat flow and hot brines, the variations in $\mathrm{O}^{18} / \mathrm{O}^{16}$ and $\mathrm{C} 13 / \mathrm{C}^{12}$ of the carbonates must be evaluated under the hypothesis that they are in isotopic equilibrium with present-day brine waters. If the observed gradient in $\mathrm{O}^{18 / \mathrm{O}^{16}}$ of the carbonates represents complete equilibration with a large reservoir of water of a isotopic composition in the range $0.5-2.5^{\circ} \%$ o the temperature gradient from top to bottom of Core 225 must span $50^{\circ}$ to $70^{\circ} \mathrm{C}$ or about $30^{\circ} \mathrm{C}$ per 100 meters. If this water were present-day Red Sea water with a $\delta \mathrm{O}^{18}$ of $+1.5 \pm 1.0^{\circ} \%$, the temperature necessary for equilibrium between carbonate water at the sediment-water interface would be $5 \pm 5^{\circ} \mathrm{C}$, an unreasonably low temperature. If the present-day brine temperature of $40^{\circ} \mathrm{C}$ is taken as the temperature of the water at the sediment-water interface, the $\delta \mathrm{O}^{18}$ of the water necessary for equilibrium with the carbonate would have to be $+9 \pm 1 \%$, a value much higher than presently exists. Therefore, the $\mathrm{O}^{18 / \mathrm{O}^{16}}$ values of the carbonates cannot reasonably represent complete isotopic reequilibration with water like that in the pore waters of Site 225 at temperatures like those observed presently. However, isotopic equilibration of the carbonate in the sediments with hot brines with a high $\mathrm{O}^{18 / \mathrm{O}^{16}}$ prior to 10,000 B.P. cannot be ruled out pending detailed investigation of the carbonate utilizing the scanning electron microscope and further isotopic studies.

\section{REFERENCES}

Clayton, R. N. and Mayeda, T. K., 1963. The use of bromine pentafluoride in the extraction of oxygen from oxides and silicates for isotopic analysis: Geochim. Cosmochim. Acta, v. 27 , p. 43.

Craig, H., 1961. Isotopic variations in meteoric waters: Science, v. 133, p. 1702.

Deuser, W. G. and Degens, E. T., 1969. O $18 / \mathrm{O}^{16}$ and $\mathrm{C}^{13} / \mathrm{C}^{12}$ ratios of fossils from the hot-brine deep area of the central Red Sea. In Degens, E. T. and Ross, D.A.,Hot brines and recent heavy metal deposits in the Red Sea: New York (Springer-Verlag), p. 336.

Lawrence, J. R., in press. Interstitial water studies, Leg 15 -stable oxygen and carbon isotope variations in water, carbonates, and silicates from the Venezuela Basin (Site 149) and the Aves Rise (Site 148). In Heezen, B. C., MacGregor, J. G., et al., Initial Reports of the Deep Sea Drilling Project, Volume 20: Washington (U. S. Government Printing Office).

McCrea, J. M., 1950. The isotopic chemistry of carbonates and a paleotemperature scale: J. Chem. Phys.,v. 18, p. 849.

O'Neil, J. R. and Epstein, S., 1966. A method for oxygen isotope analysis of milligram quantities of water and some of its applications: J. Geophys. Res., v. 71, p. 4955.

Savin, S. M. and Epstein, S., 1970. The oxygen and hydrogen isotope geochemistry of ocean sediments and shales: Geochim. Cosmochim. Acta, v. 34, p. 43. 